\title{
Analisis Pemanfaatan Program Deteksi Dini Kanker Serviks dengan IVA oleh Peserta JKN-KIS
}

\section{Utilization Analysis of Cervical Cancer Early Detection Program with VIA by JKN-KIS Participants}

\author{
Nur An Nisaa ${ }^{1^{*}}$, Antono Suryoputro ${ }^{1}$, Aditya Kusumawati ${ }^{2}$ \\ ${ }^{1}$ Departemen Administrasi dan Kebijakan Kesehatan, Fakultas Kesehatan Masyarakat, \\ Universitas Diponegoro \\ ${ }^{2}$ Departemen Pendidikan Kesehatan dan Ilmu Perilaku, Fakultas Kesehatan Masyarakat, \\ Universitas Diponegoro \\ (*annisaanur@gmail.com)
}

\begin{abstract}
ABSTRAK
Program nasional deteksi dini kanker serviks dengan pemeriksaan IVA telah didukung oleh BPJS Kesehatan, tetapi pemanfaatannya tetap rendah. Pada tahun 2017, pemanfaatan pemeriksaan IVA di Kota Semarang hanya sebesar $1,7 \%$. Penelitian ini bertujuan untuk menganalisis faktor yang berhubungan dengan pemanfaatan pelayanan pemeriksaan IVA oleh peserta JKN-KIS. Metode penelitian ini adalah kuantitatif dengan pendekatan cross-sectional. Lokasi penelitian di Kecamatan Banyumanik, Kota Semarang dengan jumlah responden 100 orang WUS, peserta aktif JKN-KIS yang telah menikah. Analisis data menggunakan uji chi-square dan regresi logistik berganda. Hasil penelitian menunjukkan bahwa sebagian besar responden belum memanfaatkan IVA (87\%), memiliki pengetahuan kurang (56\%), sikap kurang mendukung (57\%), akses terjangkau (55\%), dukungan sosial kurang $(56 \%)$, persepsi kerentanan rendah $(56 \%)$, persepsi keparahan tinggi $(52 \%)$, persepsi manfaat rendah (58\%), dan persepsi hambatan tinggi (61\%). Variabel yang memiliki hubungan secara statistik dengan pemanfaatan pemeriksaan IVA oleh peserta JKN-KIS di Kecamatan Banyumanik adalah pengetahuan $(p=0,000)$, sikap $(\mathrm{p}=0,000)$, dukungan sosial $(\mathrm{p}=0,000)$, persepsi kerentanan $(\mathrm{p}=0,002)$, persepsi manfaat $(\mathrm{p}=0,006)$, dan persepsi hambatan $(\mathrm{p}=0,003)$. Sedangkan faktor yang paling berpengaruh adalah adalah sikap $(\mathrm{p}=0,04 ; \mathrm{OR}=9,872)$. Sehingga WUS dengan sikap kurang mendukung memiliki peluang 9,872 kali lebih besar untuk tidak melakukan pemeriksaan IVA.
\end{abstract}

Kata kunci: Kanker serviks, IVA, JKN-KIS

\section{ABSTRACT}

The national program for early detection of cervical cancer by VIA has been supported by BPJS Kesehatan, but its utilization remains low. The utilization of VIA in Semarang City was only 1.7\% in 2017. The purpose of this study was to analyze the factors related to the utilization of VIA by JKN-KIS participants. This study used quantitative methods with cross-sectional approach. The research location was in Banyumanik Subdistrict with 100 women of childbearing age, active participants of JKN-KIS who were married. Data analysis used Chi-square and multiple logistic regression. The results showed that the majority of respondents had not utilized VIA (87\%), had less knowledge (56\%), unfavorable attitude (57\%), good access (55\%), less social support (56\%), low perceived vulnerability (56\%), high perceived severity (52\%), low perceived benefits (58\%), and high perceived barriers (61\%). Variables related to the utilization of VIA by JKN-KIS participants are knowledge $(p=0,000)$, attitude $(p=0,000)$, social support $(p=0,000)$, perceived vulnerability $(p=0,002)$, perceived benefits $(p=0.006)$, and perceived barriers $(p=0.003)$. While the most influential factor is attitude ( $p=0.04 ;$ OR=9.872). Thus, women with an unfavorable attitude has a probability of 9,872 times to not conduct a VIA test.

Keywords: Cervical cancer, VIA, JKN-KIS 


\section{PENDAHULUAN}

Kanker serviks merupakan jenis kanker dengan prevalensi tertinggi di Indonesia pada tahun 2013 , yaitu sebesar $0,8 \%{ }^{1}{ }^{1}$ Kanker serviks adalah jenis tumor ganas yang menyerang daerah leher rahim atau mulut rahim dan disebabkan oleh infeksi HPV (Human Papilloma Virus). ${ }^{2}$ Angka kejadian kanker serviks di Indonesia pada tahun 2015 adalah 17/100.000 wanita per tahun. Indonesia berada pada urutan ke 4 dengan kejadian kanker serviks tertinggi di Asia Tenggara, setelah Kamboja, Myanmar, dan Thailand. ${ }^{3}$

Angka kematian akibat kanker serviks di Indonesia masih tinggi. Pada tahun 2014, WHO memperkirakan sekitar $10,3 \%$ dari 92.200 kematian atau sekitar 9.457 kematian pada wanita akibat kanker di Indonesia disebabkan oleh kanker serviks. ${ }^{4}$ Sebagian besar kasus kematian ini disebabkan oleh keterlambatan diagnosis, kanker ditemukan pada stadium lanjut.

Kanker serviks merupakan jenis kanker yang dapat dicegah dengan vaksin dan deteksi dini atau skrining. Program skrining yang efektif dapat membantu menurunkan angka kesakitan dan kematian akibat kanker serviks secara signifikan. ${ }^{5}$ Terdapat tiga jenis tes skrining untuk menemukan dan mendeteksi dini kanker serviks, yaitu: pap smear, tes HPV-DNA dan pemeriksaan dengan pendekatan visual (IVA) ${ }^{5}$

IVA (Inspeksi Visual Asam Asetat) direkomendasikan oleh WHO sebagai metode deteksi dini kanker serviks yang tepat untuk diterapkan di negara berkembang dengan sumberdaya yang terbatas. ${ }^{67}$ IVA memiliki tingkat sensitivitas dan spesivisitas yang cukup tinggi. ${ }^{7}$

Menteri Kesehatan Republik Indonesia mengeluarkan Peraturan Menteri Kesehatan nomor 34 tahun 2015 yang salah satu isinya memuat tentang pengendalian kanker serviks melalui pemeriksaan IVA dengan sasaran target yaitu perempuan berusia 30-50 tahun. Persentase perempuan usia 30-50 tahun yang melakukan deteksi dini kanker serviks merupakan salah satu indikator keberhasilan pembangunan kesehatan. Target yang diharapkan dapat tercapai pada tahun 2019 yaitu sebesar 50\%. ${ }^{8}$ Layanan deteksi dini kanker serviks dengan pemeriksaan IVA termasuk dalam skema pembiayaan JKN-KIS yang dijamin oleh BPJS Kesehatan. ${ }^{9}$ Jaminan ini diberikan bagi seluruh wanita usia produktif yang telah menjadi peserta JKN-KIS dan dapat dimanfaatkan di fasilitas kesehatan tingkat pertama seperti puskesmas.

Provinsi Jawa Tengah merupakan wilayah dengan perkiraan penderita kanker serviks terbanyak kedua dibawah Provinsi Jawa Timur, yaitu sebesar 19.734 orang. ${ }^{1}$ Kota Semarang merupakan wilayah di Provinsi Jawa Tengah dengan jumlah kasus baru kanker serviks tertinggi, yaitu sebesar 361 orang. ${ }^{10}$ Kasus baru kanker serviks di Kota Semarang cenderung mengalami kenaikan setiap tahunnya. Data terakhir pada tahun 2017 melaporkan terdapat 367 kasus baru kanker serviks. ${ }^{11} \mathrm{Ka}$ sus kanker serviks di Kota Semarang menempati posisi kedua pada jenis kanker dengan penderita terbesar setelah kanker payudara.

Studi pendahuluan di Dinas Kesehatan Kota Semarang menunjukkan bahwa 14 dari 37 puskesmas di Kota Semarang telah mampu memberikan pelayanan pemeriksaan IVA. Namun, tingkat pemanfaatan program deteksi dini kanker serviks dengan pemeriksaan IVA di Kota Semarang belum optimal. Berdasarkan Profil Kesehatan Kota Semarang tahun 2015, capaian program ini hanya $0,13 \%$ saja. Kemudian pada tahun 2016 mengalami kenaikan, yaitu menjadi $0,17 \%$ dan data terbaru pada tahun 2017, menunjukkan capaian program yang meningkat signifikan yaitu sebesar $1,5 \%$. Namun, capaian program ini belum memenuhi target nasional untuk tahun 2017 yaitu sebesar 30\%.

Tolok ukur keberhasilan program deteksi dini kanker serviks ada pada pemanfaatan pelayanan pemeriksaan IVA oleh perempuan usia 30-50 tahun. Selama tiga tahun keberjalanannya, indikator ini belum pernah mencapai target yang diharapkan. Padahal pemerintah pusat dan daerah telah melakukan sejumlah upaya untuk meningkatkan kesadaran dan minat WUS, khususnya di era Jaminan Kesehatan Nasional saat ini. Tujuan dari penelitian ini adalah untuk mengetahui faktor-faktor yang diduga berhubungan dengan pemanfaatkan pelayanan pemeriksaan IVA oleh WUS sebagai peserta JKN-KIS.

\section{BAHAN DAN METODE}

Metode penelitian ini adalah kuantitatif, dengan pendekatan analitik observasional dan rancangan studi cross-sectional. Teori yang di- 
gunakan sebagai acuan dalam penelitian ini adalah modifikasi dari Behavioral Model of Health Service Use dan Health Belief Model. Sehingga variabel pada penelitian ini adalah umur, tingkat pendidikan, status pekerjaan, pengetahuan, sikap, akses, dukungan sosial, persepsi kerentanan, keparahan, manfaat dan hambatan. Penelitian dilakukan di Kecamatan Banyumanik. Dari enam belas kecamatan di Kota Semarang, Kecamatan Banyumanik merupakan wilayah yang diperkirakan dapat mewakili populasi WUS di Kota Semarang. Hal ini karena Kecamatan Banyumanik memiliki proporsi wanita usia 30-50 tahun sebesar 0,33 yang mana tidak jauh berbeda dengan proporsi wanita usia 30-50 di Kota Semarang yaitu 0,31. Selain itu, wilayah ini telah memiliki satu puskesmas yang mampu memberikan pelayanan IVA, yaitu Puskesmas Srondol.

Populasi penelitian ini adalah WUS yang telah menikah, peserta aktif JKN-KIS yang tinggal di Kecamatan Banyumanik dengan jumlah sebanyak 18.523 orang. Sampel penelitian ini berjumlah 100 orang, dengan teknik proportional random sampling. Teknik ini membagi besar sampel berdasarkan proporsi wanita usia subur pada 11 kelurahan di Kecamatan Banyumanik. Data sekunder yang diperoleh dari 4 puskesmas di Kecamatan Banyumanik dari pendataan Program Indonesia Sehat (PIS) berupa daftar nama kepala keluarga peserta JKN-KIS dan alamat rumah kemudian diundi secara acak menggunakan bantuan software Microsoft excel untuk penentuan calon responden. Penelitian dilakukan dengan bantuan kuesioner yang ditanyakan langsung kepada responden saat kunjungan ke rumah.

Uji kelayakan instrumen penelitian dilaksanakan di Kecamatan Tembalang dengan jumlah responden sebanyak 30 orang dan menggunakan bantuan uji statistik Pearson Product Moment. Kecamatan Tembalang dipilih karena memiliki karakteristik yang mirip dengan Kecamatan Banyumanik, yaitu proporsi wanita usia 30-50 tahun sebesar 0.35 dan sudah memiliki satu puskesmas pelaksana IVA, yaitu Puskesmas Kedungmundu. Hasil dari uji validitas dan reliabilitas menunjukkan bahwa seluruh item pertanyaan adalah valid dan reliabel.

Data yang diperoleh kemudian direkap menggunakan Microsoft excel 2016. Selanjutnya data tersebut dipindahkan ke software peng- olahan statistik, IBM SPPS Statistic 19 untuk dilakukan analisis lanjutan. Uji pertama yang dilakukan adalah uji normalitas yang bertujuan untuk menentukan titik potong (cut of point) dalam pengkategorian jumlah skor tiap variabel. Setelah itu dapat dilanjutkan dengan analisi univariat berupa penampilan frekuensi, mean (ratarata) dan median. Kemudian dilakukan uji bivariat untuk melihat korelasi tiap variabel dengan uji chi-square, dan untuk mengetahui faktor yang paling berpengaruh dalam penelitian maka dilakukan uji statistik terakhir, yaitu uji Regresi Logistic berganda.

\section{HASIL}

Tabel 1 menunjukkan bahwa karakteristik responden dalam penelitian ini secara umum ber-

Tabel 1. Distribusi Frekuensi Karakteristik Demografi Responden

\begin{tabular}{lll}
\hline \multicolumn{1}{c}{ Karakteristik } & $\mathbf{n}$ & $\mathbf{\%}$ \\
\hline Umur & & \\
$\quad$ Dewasa awal & 63 & 63 \\
$\quad$ Dewasa madya & 47 & 37 \\
Tingkat Pendidikan & & \\
$\quad$ Pendidikan dasar & 20 & 20 \\
$\quad$ Pendidikan tinggi & 80 & 80 \\
Status Pekerjaan & & \\
$\quad$ Bekerja & 60 & 60 \\
$\quad$ Tidak Bekerja & 40 & 40 \\
\hline
\end{tabular}

Tabel 2. Distribusi Frekuensi Pemanfaatan Pemeriksaan IVA

\begin{tabular}{lcc}
\hline \multicolumn{1}{c}{ Variabel } & n & $\mathbf{\%}$ \\
\hline Status Periksa IVA & & \\
$\quad$ Ya & 13 & 13 \\
$\quad$ Tidak & 87 & 87 \\
Frekuensi Periksa & & \\
$\quad 1$ kali & 10 & 76.9 \\
$\quad 2$ kali & 3 & 23.1 \\
Tahun Pemeriksaan & & \\
$\quad \leq 1$ tahun lalu & 6 & 46.2 \\
$\quad$ - 5 tahun lalu & 6 & 46.2 \\
$\quad$ 5 tahun lalu & 1 & 7.6 \\
Lokasi Periksa & & \\
$\quad$ Puskesmas & 4 & 30.8 \\
$\quad$ IVA masal dirumah & 6 & 46.1 \\
$\quad$ IVA masal di institusi pemerintah & 3 & 23.1 \\
Pembiayaan & & \\
$\quad$ Ditanggung BPJS & 4 & 30.8 \\
$\quad$ Tidak ditanggung BPJS & 9 & 69.2 \\
\hline
\end{tabular}


Tabel 3. Tabulasi Silang Variabel Penelitian dengan Pemanfaatan Pemeriksaan IVA

\begin{tabular}{|c|c|c|c|c|c|c|c|}
\hline \multirow{3}{*}{ Variabel } & \multicolumn{4}{|c|}{ Pemanfaatan IVA } & \multirow{2}{*}{\multicolumn{2}{|c|}{ Jumlah }} & \multirow{3}{*}{ p-value } \\
\hline & \multicolumn{2}{|c|}{ Tidak } & \multicolumn{2}{|c|}{ Ya } & & & \\
\hline & $\mathrm{n}=87$ & $\%$ & $n=13$ & $\%$ & $n=100$ & $\%$ & \\
\hline \multicolumn{8}{|l|}{ Umur } \\
\hline Dewasa Awal & 57 & 90.5 & 6 & 9.5 & 63 & 100 & \multirow[t]{2}{*}{0,222} \\
\hline Dewasa Madya & 30 & 81.1 & 7 & 18.9 & 37 & 100 & \\
\hline \multicolumn{8}{|l|}{ Tingkat Pendidikan } \\
\hline Pendidikan Dasar & 18 & 90.0 & 2 & 10.0 & 20 & 100 & \multirow[t]{2}{*}{1,0} \\
\hline Pendidikan Tinggi & 69 & 86.3 & 11 & 13.8 & 80 & 100 & \\
\hline \multicolumn{8}{|l|}{ Status Pekerjaan } \\
\hline Tidak Bekerja & 54 & 90.0 & 6 & 10.0 & 60 & 100 & \multirow[t]{2}{*}{0,275} \\
\hline Bekerja & 33 & 82.5 & 7 & 17.5 & 40 & 100 & \\
\hline \multicolumn{8}{|l|}{ Tingkat Pengetahuan } \\
\hline Kurang & 56 & 100 & 0 & 0 & 56 & 100 & \multirow[t]{2}{*}{0,000} \\
\hline Baik & 31 & 70.5 & 13 & 29.5 & 44 & 100 & \\
\hline \multicolumn{8}{|l|}{ Sikap } \\
\hline Kurang Mendukung & 56 & 98.2 & 1 & 1.8 & 57 & 100 & \multirow[t]{2}{*}{0,000} \\
\hline Mendukung & 31 & 72.1 & 12 & 27.9 & 43 & 100 & \\
\hline \multicolumn{8}{|l|}{ Akses } \\
\hline Kurang Terjangkau & 41 & 91,1 & 4 & 8,9 & 45 & 100 & \multirow[t]{2}{*}{0,269} \\
\hline Terjangkau & 46 & 83,6 & 9 & 16,4 & 55 & 100 & \\
\hline \multicolumn{8}{|l|}{ Dukungan Sosial } \\
\hline Kurang & 56 & 100 & 0 & 0 & 56 & 100 & \multirow[t]{2}{*}{0,000} \\
\hline Baik & 31 & 70.5 & 13 & 29.5 & 44 & 100 & \\
\hline \multicolumn{8}{|l|}{ Persepsi Kerentanan } \\
\hline Rendah & 54 & 96.4 & 2 & 3.6 & 56 & 100 & \multirow[t]{2}{*}{0,002} \\
\hline Tinggi & 33 & 75.0 & 11 & 25.0 & 44 & 100 & \\
\hline \multicolumn{8}{|l|}{ Persepsi Keparahan } \\
\hline Rendah & 42 & 87.5 & 6 & 12.5 & 48 & 100 & \multirow[t]{2}{*}{0,886} \\
\hline Tinggi & 45 & 86.5 & 7 & 13.5 & 52 & 100 & \\
\hline \multicolumn{8}{|l|}{ Persepsi Manfaat } \\
\hline Rendah & 55 & 94.8 & 3 & 7.5 & 58 & 100 & \multirow[t]{2}{*}{0,006} \\
\hline Tinggi & 32 & 76.2 & 10 & 23.8 & 42 & 100 & \\
\hline \multicolumn{8}{|l|}{ Persepsi Hambatan } \\
\hline Tinggi & 58 & 95.1 & 3 & 4.9 & 61 & 100 & 0,003 \\
\hline Rendah & 29 & 74.4 & 10 & 25.6 & 39 & 100 & \\
\hline
\end{tabular}

ada pada kelompok umur dewasa awal (18-40 tahun) sebesar $63 \%$, dengan rata-rata usia responden adalah 38 tahun. Selain itu, sebagian besar responden telah menempuh pendidikan tinggi (80\%), tidak bekerja/Ibu Rumah Tangga (60\%) dan memiliki jenis kepesertaan non PBI (77\%).

Tabel 2 dapat diketahui bahwa responden yang melakukan pemeriksaan IVA proporsinya masih rendah, yaitu hanya sebesar $13 \%$. Selain itu, sebagian besar pembiayaan pelayanan tersebut tidak ditanggung BPJS Kesehatan $(69,2 \%)$. Oleh karena sebagian besar responden melakukan pemeriksaan IVA saat kegiatan IVA masal di lingkungan rumah $(46,1 \%)$ yang tidak bekerja sama dengan BPJS Kesehatan. Selain itu, ditemukan pula peraturan teknis mengenai pembiayaan pemeriksaan IVA oleh BPJS Kesehatan, yaitu harus terdaftar di fasilitas kesehatan tingkat pertama yang juga pelaksana pemeriksaan IVA. Dari empat puskesmas di Kecamatan Banyumanik, hanya Puskesmas Srondol yang telah mampu memberikan pelayanan pemeriksaan IVA.

Hasil analisis univariat pada penelitian ini menunjukkan bahwa sebagian besar responden memiliki pengetahuan yang kurang (56\%), sikap yang kurang mendukung (57\%), akses menuju 
Tabel 4. Model Akhir Regresi Logistik

\begin{tabular}{lcccccc}
\hline \multicolumn{1}{c}{ Variabel Independen } & B & S.E & Wald & df & Sig. & Exp(B) \\
\hline Sikap & 2,290 & 1,113 & 4,236 & 1 & 0,040 & 9,872 \\
Persepsi Kerentanan & 1,782 & 0,866 & 4,236 & 1 & 0,040 & 5,941 \\
Persepsi Manfaat & 0,949 & 0,803 & 1,395 & 1 & 0,238 & 2,583 \\
Persepsi Hambatan & 1,495 & 0,779 & 3,681 & 1 & 0,055 & 4,457 \\
Constant & $-2,796$ & 0,629 & 19,763 & 1 & 0,000 & 0,061 \\
\hline
\end{tabular}

fasilitas pelayanan kesehatan yang baik/terjangkau (55\%), dukungan lingkungan sosial yang kurang $(56 \%)$, persepsi kerentanan yang rendah $(56 \%)$, persepsi keparahan yang tinggi (52\%), persepsi manfaat yang rendah $(58 \%)$, dan persepsi hambatan yang tinggi $(61 \%)$.

Selanjutnya dilakukan analisis bivariat yang menunjukkan hasil bahwa 6 dari 11 variabel dalam penelitian ini memiliki hubungan yang signifikan dengan pemanfaatan pelayanan pemeriksaan IVA oleh peserta JKN-KIS (Tabel 3). Kemudian untuk mengetahui faktor yang paling berpengaruh, maka dilakukan uji multivariat. Hasil uji multivariat menggunakan regresi logistic menunjukkan bahwa faktor yang paling berpengaruh terhadap pemanfaatan pemeriksaan IVA oleh peserta JKNKIS adalah sikap WUS terhadap IVA $(\mathrm{p}=0,040$; $\mathrm{OR}=9,872$ ) (Tabel 4).

\section{PEMBAHASAN}

Umur tidak memiliki hubungan yang bermakna secara statistik dengan pemanfaatan pemeriksaan IVA oleh peserta JKN-KIS. Hasil penelitian ini sejalan dengan Pandey, tetapi tidak sejalan dengan Chang. Menurut Chang, pertambahan usia memungkinkan masalah kandungan semakin tinggi sehingga seorang wanita akan lebih sering untuk kontak dengan klinik kandungan dan lebih memungkinkan untuk mendapat saran terkait deteksi dini kanker serviks. ${ }^{12}$ Selain itu, secara psikologis, pertambahan usia seseorang umumnya diimbangi dengan perasaan lebih rentan terhadap masalah kesehatan sehingga cenderung melakukan upaya pencegahan. ${ }^{13}$ Namun, hal tersebut tidak terbukti dalam penelitian ini karena sebagian besar responden memiliki tingkat pengetahuan yang rendah terhadap kanker serviks dan upaya deteksi dini. Pengetahuan yang rendah dapat menimbulkan persepsi yang kurang tepat mengenai kebutuhan diri terhadap pelayanan kesehatan dan kesadaran diri yang rendah. ${ }^{14}$

Tingkat pendidikan tidak memiliki hubungan yang bermakna secara statistik dengan pemanfaatan pemeriksaan IVA oleh peserta JKNKIS. Hasil penelitian ini sejalan dengan penelitian Wahyuni sedangkan penelitian Nasihah menyatakan ada hubungan bermakna antara tingkat pendidikan dengan perilaku periksa IVA karena wanita dengan pendidikan tinggi cenderung memiliki pengetahuan yang baik terkait risiko kanker serviks dan upaya pencegahannya. ${ }^{15}$ Namun, hal tersebut tidak terbukti dalam penelitian ini. Meskipun $80 \%$ responden telah menempuh pendidikan tinggi namun hanya $44 \%$ responden yang memiliki pengetahuan baik terkait kanker serviks dan upaya deteksi dini.

Status pekerjaan tidak memiliki hubungan yang bermakna secara statistik dengan pemanfaatan pemeriksaan IVA oleh peserta JKN-KIS. Hasil penelitian ini sejalan dengan penelitian Yuliwati dan Safa'ah yang menyatakan bahwa kesibukan wanita yang bekerja menyebabkan mereka tidak memiliki waktu untuk periksa IVA. ${ }^{16,17}$ Selain itu, rendahnya penyampaian informasi kesehatan serta lingkungan pekerjaan tidak memberi izin dan tidak memfasilitasi pemeriksaan IVA juga menjadi latar belakang rendahnya partisipasi wanita bekerja dalam skrining kanker. ${ }^{18}$

Tingkat pengetahuan memiliki hubungan yang bermakna secara statistik dengan pemanfaatan pemeriksaan IVA oleh peserta JKN-KIS. Hasil penelitian ini sejalan dengan Mirayashi, sedangkan penelitian Parapat menyatakan bahwa meskipun memiliki pengetahuan yang baik, tetapi rasa takut dan persepsi ibu mengenai penyakit yang ditemukan dini dapat membebani pikiran dapat menyebabkan rendahnya perilaku periksa IVA. ${ }^{19,20}$ Sebagian besar responden dalam penelitian ini memiliki pengetahuan yang kurang baik mengenai kanker serviks (tanda dan gejala, faktor 
risiko, cara pencegahan dan jenis pengobatan), upaya deteksi dini, pemeriksaan IVA dan manfaat kepesertaan JKN-KIS yang dimiliki. Pengetahuan yang kurang disebabkan oleh rendahnya minat untuk mencari informasi terkait kanker serviks. ${ }^{21}$ Selain itu, lingkungan sosial yang kurang mendukung (56\%) menyebabkan penyampaian informasi kesehatan juga rendah.

Sikap memiliki hubungan yang bermakna secara statistik dengan pemanfaatan pemeriksaan IVA oleh peserta JKN-KIS. Hasil penelitian ini tidak sejalan dengan Parapat dan Nordianti yang menyatakan bahwa sikap yang baik jika tidak ditindaklanjuti maka tidak akan menimbulkan praktik IVA. ${ }^{20,22}$ Sebagian besar responden dalam penelitian ini memiliki sikap kurang mendukung terhadap pelayanan pemeriksaan IVA. Sikap yang kurang mendukung atau bahkan menolak program kesehatan dapat timbul karena rendahnya paparan informasi dan pengalaman di masa lalu. ${ }^{23}$

Akses tidak memiliki hubungan yang bermakna secara statistik dengan pemanfaatan pemeriksaan IVA oleh peserta JKN-KIS. Hal ini karena masih rendahnya pengetahuan wanita usia subur terkait program deteksi dini kanker serviks dengan pemeriksaan IVA. Meskipun jarak tempuh, waktu tempuh dan biaya transportasi yang terjangkau, namun jika tidak mengetahui tentang pemeriksaan IVA dan dimana pelayanan tersebut dapat diperoleh, maka wanita usia subur tidak akan memanfaatkan pelayanan tersebut. Hasil penelitian ini sejalan dengan Pertiwi, tetapi hasil penelitian ini tidak sejalan dengan Rohmawati yang menyatakan bahwa ada hubungan yang bermakna antara kemudahan akses dan keterjangkauan jarak menuju fasilitas pelayanan kesehatan dengan perilaku periksa IVA. ${ }^{24}$

Dukungan lingkungan sosial memiliki hubungan yang bermakna secara statistik dengan pemanfaatan pemeriksaan IVA oleh peserta JKNKIS. Dukungan lingkungan sosial memiliki peran penting dalam penyampaian informasi terkait kanker serviks dan deteksi dini. ${ }^{25}$ Ketika seorang wanita memiliki seseorang atau sekelompok orang terdekat dengan pengetahuan dan pemahaman yang lebih baik mengenai kesehatan, maka mereka akan menjadi salah satu faktor yang memperkuat alasan untuk melakukan periksa IVA. ${ }^{16}$ Hasil penelitian ini sejalan dengan Nordianti, tetapi tidak sejalan dengan Safa'ah. Pada penelitian Safa'ah menyatakan bahwa meskipun lingkungan sosial mendukung namun jika tidak diimbangi dengan pengetahuan dan kesadaran diri yang baik, maka tidak akan terwujud praktik periksa IVA. ${ }^{17,22}$

Persepsi kerentanan memiliki hubungan yang bermakna secara statistik dengan pemanfaatan pemeriksaan IVA oleh peserta JKN-KIS. Hasil penelitian ini sejalan dengan Kamberi dan Palupi, yang menyatakan bahwa seorang individu dengan persepsi kerentanan yang tinggi akan melakukan usaha untuk mencegah terjadinya penyakit tersebut dengan melakukan deteksi dini. ${ }^{26,27}$ Dalam penelitian ini, sebagian besar responden memiliki persepsi kerentanan yang rendah karena merasa dirinya tidak berisiko terkena kanker serviks. Hal ini terjadi karena rendahnya pengetahuan responden, sehingga menimbulkan persepsi bahwa mereka tidak memiliki risiko karena merasa dirinya telah berperilaku sehat.

Persepsi keparahan tidak memiliki hubungan yang bermakna secara statistik dengan pemanfaatan pemeriksaan IVA oleh peserta JKNKIS. Sebagian besar responden dalam penelitian ini memiliki persepsi keparahan yang tinggi (52\%) terhadap kanker serviks. Namun, karena tidak mengenal dan tidak mengetahui upaya deteksi dini, maka tidak akan menghasilkan praktik periksa IVA. ${ }^{28}$ Hasil penelitian ini sejalan dengan Hoque, tetapi tidak sejalan dengan Kamberi. Kamberi menyatakan bahwa semakin tinggi persepsi keparahan maka semakin besar pula upaya yang individu lakukan untuk pencegahan. ${ }^{27,28}$ Persepsi manfaat memiliki hubungan yang bermakna secara statistik dengan pemanfaatan pemeriksaan IVA oleh peserta JKN-KIS. Persepsi manfaat yang rendah terjadi karena rendahnya pengetahuan wanita usia subur terkait manfaat dari upaya deteksi dini kanker serviks. ${ }^{29} \mathrm{Hal}$ ini menyebabkan timbulnya perasaan tidak yakin bahwa pemeriksaan IVA dapat menurunkan risiko kanker serviks. Hasil penelitian ini sejalan dengan penelitian Secginli, et al., dan Oktaviana, yang menyatakan bahwa dengan mengetahui manfaat dari pemeriksaan IVA maka wanita usia subur akan lebih tertarik dan menyadari tentang pentingnya deteksi dini..$^{30,31}$

Persepsi hambatan memiliki hubungan yang bermakna secara statistik dengan pemanfaatan pemeriksaan IVA oleh peserta JKN-KIS. Persep- 
si hambatan yang dirasakan oleh sebagian besar responden berupa rasa tidak nyaman ketika organ kewanitaan diperiksa, rasa takut terhadap hasil pemeriksaan, rasa ragu terhadap keakuratan IVA, dan alasan kesibukan, Persepsi hambatan yang tinggi timbul karena rendahnya pengetahuan WUS terkait upaya deteksi dini dan fasilitas pelayanan kesehatan sehingga menyebabkan persepsi yang salah. ${ }^{32}$ Hasil penelitian ini sejalan dengan penelitian Secginli, et al dan Oktaviana, yang menyatakan bahwa persepsi ini menyebabkan WUS enggan untuk melakukan skrining, sehingga persepsi hambatan yang tinggi memiliki korelasi negatif terhadap praktik skrining..$^{30,31}$

Hasil uji multivariat menggunakan regresi logistic menunjukkan bahwa dari kesebelas variabel diatas, sikap WUS terhadap pemeriksaan IVA merupakan variabel yang paling berpengaruh terhadap pemanfaatan pemeriksaan IVA oleh peserta JKN-KIS. Seorang wanita usia subur dengan sikap yang kurang mendukung terhadap program deteksi dini kanker serviks dengan metode IVA berpeluang 9,872 kali lebih besar untuk tidak melakukan pemeriksaan IVA dibandingkan dengan wanita usia subur yang memiliki sikap mendukung dan terbuka terhadap program deteksi dini kanker serviks. Sejalan dengan penelitian sebelumnya, Yanikkerem menyatakan bahwa sikap dan kesadaran terhadap program deteksi dini kanker serviks merupakan jembatan yang mengubah pengetahuan menjadi praktik. ${ }^{33}$ Selain itu, penelitian oleh Mosavel menunjukkan bahwa wujud sikap seperti "penyakit kanker serviks adalah takdir" merupakan hal yang fatal dan berkaitan erat dengan sikap pasif terhadap upaya untuk melakukan deteksi dini. ${ }^{34}$

\section{KESIMPULAN DAN SARAN}

Berdasarkan penelitian, maka dapat disimpulkan bahwa pemanfaatan pelayanan pemeriksaan IVA oleh peserta JKN-KIS di Kecamatan Banyumanik masih rendah (13\%). Variabel yang berhubungan adalah tingkat pengetahuan, sikap, dukungan sosial, persepsi kerentanan, persepsi manfaat, dan persepsi hambatan. Faktor yang memiliki pengaruh paling signifikan adalah sikap. Sehingga, WUS dengan sikap kurang mendukung terhadap pemeriksaan IVA memiliki peluang 9,872 kali lebih besar untuk tidak melakukan IVA.
Disarankan bagi Dinas Kesehatan Kota Semarang untuk meningkatkan pemahaman masyarakat (bukan hanya WUS) terhadap risiko kanker serviks, meningkatkan akses terhadap fasilitas pelayanan kesehatan dengan meningkatkan jumlah tenaga kesehatan terlatih IVA dan menggencarkan IVA massal untuk lingkup kecamatan/kelurahan. Bagi BPJS Kesehatan Kantor Cabang Kota Semarang disarankan untuk membangun sistem terintegrasi antara puskesmas yang belum melayani IVA dengan puskesmas yang sudah mampu melayani IVA dan meningkatkan penyampaian informasi kepada masyarakat terkait pelayanan kesehatan yang dibiayai oleh BPJS Kesehatan. Bagi Puskesmas Kota Semarang, disarankan untuk meningkatkan kualitas penyampaian informasi terkait kanker serviks bukan hanya kepada kader tapi juga suami \& anggota keluarga lainnya, serta menyampaikan informasi secara langsung kepada WUS yang berkunjung ke puskesmas, mengenai kanker serviks dan upaya deteksi dini.

\section{DAFTAR PUSTAKA}

1. Kementerian Kesehatan RI Pusat Data dan Informasi Kesehatan. Infodatin-Kanker. Jakarta; Kementerian Kesehatan RI; 2015.

2. Rasjidi I. Epidemiologi Kanker pada Wanita. Jakarta. Sagung Seto; 2010.

3. Nurcahyanti ADR. Cervical Cancer: The Case in Indonesia and Natural Product-Based Therapy. Journal of Cancer Biology \& Research. 2016;4(1):1078.

4. World Health Organization. Cancer Country Profiles: Indonesia. Cancer Country Profiles; 2014.

5. Herdman C, Sherris J, Bishop A, Burns M, Coffey P, Erickson J, et al. Planning Appropriate Cervical Cancer Prevention Programs. 2nd ed. PATH (Program for Appropriate Technology in Health). Seattle. 2000:5-40.

6. Kementerian Kesehatan Republik Indonesia. Panduan Program Nasional Gerakan Pencegahan dan Deteksi Dini Kanker Leher Rahim dan Kanker Payudara. Jakarta: Kementerian Kesehatan RI. 2015;(April):1-47.

7. World Health Organization. Screening for Cervical Cancer in Developing Countries. Report of A WHO Consultation. Geneva. 2002; 89. 
8. Kementerian Kesehatan Republik Indonesia. Rencana Strategis Kementerian Kesehatan Tahun 2015-2019. Jakarta: Kementerian Keseha$\tan$ RI; 2015.

9. BPJS Kesehatan. Info BPJS Kesehatan: BPJS Kesehatan Optimalkan Fungsi Promotif dan Preventif. Media Eksternal BPJS Kesehatan. 2016; Edisi 35.

10. Dinas Kesehatan Provinsi Jawa Tengah. Profil Kesehatan Provinsi Jawa Tengah Tahun 2016. Semarang: Dinas Kesehatan Provinsi Jawa Tengah; 2016.

11. Dinas Kesehatan Kota Semarang. Profil Kesehatan Kota Semarang Tahun 2016. Semarang: Dinas Kesehatan Kota Semarang; 2016.

12. Chang-claude J, Eby N, Kiechle M, Bastert G, Becher H. Breastfeeding and Breast Cancer Risk by Age 50 Among Women in Germany. Cancer Causes Control. 2000;11(8):687-95.

13. Sarafino E. Health Psychology: Biopsychosocial Interactions. 2nd ed. Oxford, England: John Wiley \& Sons; 1994.

14. Rosser JI, Njoroge B, Huchko MJ. Knowledge About Cervical Cancer Screening and Perception of Risk Among Women Attending Outpatient Clinics in Rural Kenya. International Journal of Gynecology \& Obstetrics. 2015;128(3):211-215.

15. Nasihah M, B SL. Hubungan Antara Pengetahuan dan Pendidikan dengan Pelaksanaan Deteksi Dini Kanker Serviks Melalui IVA. Jurnal Midpro. 2013;Edisi 2:20-26.

16. Yuliwati. Faktor-Faktor yang Berhubungan dengan Perilaku WUS dalam Deteksi Dini Kanker Leher Rahim Metode IVA di Wilayah Puskesmas Prembun Kabupaten Kebumen Tahun 2012. [Skripsi]. Depok: Universitas Indonesia; 2012.

17. Safa'ah N. Faktor-Faktor yang Berhubungan dengan Motivasi Wanita Usia Subur yang Melakukan Pemeriksaan IVA dalam Upaya Deteksi Kanker Serviks. [Skripsi]. Tuban: STIKES NU Tuban; 2009.

18. Chang HK, Myong JP, Byun SW, Lee SJ, Lee YS, Lee HN, et al. Factors Associated with Participation in Cervical Cancer Screening Among Young Koreans: A Nationwide Cross-sectional Study. BMJ Open Journals. 2017;7(4):1-9.
19. Mirayashi D, Rahrjo W, Wicaksono A. Hubungan Antara Tingkat Pengetahuan Tentang Kanker Serviks dengan Keikutsertaan Melakukan Pemeriksaan Inspeksi Visual Asetat di Puskesmas Alianyang Pontianak. Jurnal Mahasiswa PSPD FK Univ Tanjungpura. 2014;1(1):1-17.

20. Parapat FT. Faktor-Faktor yang Berhubungan dengan Perilaku Deteksi Dini Kanker Leher Rahim Metode Inspeksi Visual Asam Asetat di Puskesmas Candiroto Kabupaten Temanggung. Universitas Diponegoro; 2016.

21. Sulistiowati E, Sirait AM. Pengetahuan Tentang Faktor Risiko, Perilaku dan Deteksi Dini Kanker Serviks dengan Inspeksi Visual Asam Asetat (IVA) pada Wanita di Kecamatan Bogor Tengah, Kota Bogor. Buletin Penelitian Kesehatan. 2014;42(3):193-202.

22. Nordianti ME, Wahyono B. Determinan Kunjungan Inspeksi Visual Asam Asetat di Puskesmas Kota Semarang. Higeia Journal Public Health Research and Development. 2017;1(2):33-44.

23. Duran E. Examination with the Health Belief Model of women's Attitudes to Cervical Cancer and Early Diagnosis in Turkey: A Qualitative Study. Asian Pac J Cancer Prev. 2011;12(5):1179-84.

24. Rohmawati I. Faktor-Faktor yang Berhubungan dengan Perilaku Wanita Usia Subur dalam Deteksi Dini Kanker Serviks dengan Metode IVA (Inspeksi Visual dengan Asam Asetat) di Wilayah Kerja Pukesmas Ngawen I Kabupaten Gunung Kidul Tahun 2011. Universitas Indonesia; 2011.

25. Jensen LF, Pedersen AF, Andersen B, Vedsted P. Social Support and Non-participation in Breast Cancer Screening: A Danish Cohort Study. Journal of Public Health. 2016;38(2):335-342.

26. Palupi ERR. Analisis Faktor yang Berhubungan dengan Pemeriksaan Inspeksi Visual Asam Asetat (IVA) pada Wanita Pasangan Usia Subur Berdasarkan Health Belief Model di Wilayah Polindes Tanjunganom. [Skripsi]. Universitas Airlangga; 2016.

27. Kamberi F, Theodhosi G, Ndreu V, Sinaj E, Cuberi D, Kamberi L. Vlora's Women and Cervical Cancer Health Beliefs. Eur Sci J. 
2015;2:150-158.

28. Hoque M, Ibekwe CM, Ntuli-Ngcobo B. Screening and Perceived Severity of Cervical Cancer Among Women Attending Mahalapye District Hospital, Botswana. Asian Pacific Journal of Cancer Prevention. 2009;10(6):1095-1100.

29. Khosidah A, Trisnawati Y. Faktor-Faktor yang Mempengaruhi Ibu Rumah Tangga dalam Melakukan Tes IVA Sebagai Upaya Deteksi Dini Kanker Serviks. Jurnal Ilmiah Kebidanan. 2015;6(2):94-105.

30. Secginli S, Nahcivan NO. Factors Associated with Breast Cancer Screening Behaviours in a Sample of Turkish Women: A Questionnaire Survey. International Jornal Nursing Studies. 2006;43(2):161-171.

31. Oktaviana MN. Hubungan Antara Persepsi Kerentanan Individu, Keseriusan Penyakit,
Manfaat dan Hambatan dengan Wanita, Penggunaan Skrining Inspeksi Visual Asam Asetat Pada Wanita Subur. [Tesis]. Surakarta: Universitas Sebelas Maret; 2015.

32. Abotchie PN, Shokar NK. Cervical Cancer Screening Among College Students in Ghana. International Journal of Gynecological Cancer. 2009;19(3):412-416.

33. Emre Y, Aslı Karakuş S, Nicole E. Women's Attitude and Beliefs about Cervical Cancer and Pap Smear Test by Using the Health Belief Model. International Journal Cancer and Clinical Research. 2018;5(3):1-9.

34. Mosavel M, Simon C, Oakar C, Meyer S. Cervical Cancer Attitudes and Beliefs - A Cape Town Community Responds on World Cancer Day. Journal of Cancer Education. 2009;24(2) (2):114-119. 